\title{
Future Quality in the Emergent European Higher Education Area Involves the Use of Informatics
}

\author{
Javier BILBAO, Eugenio BRAVO, Olatz GARCÍA, \\ Concepción VARELA, Miguel RODRÍGUEZ, \\ Purificación GONZÁLEZ \\ Department of Applied Mathematics, Engineering School of Bilbao \\ University of the Basque Country \\ Alda. Urkijo, s/n, 48013 Bilbao, Spain \\ e-mail: \{javier.bilbao, eugenio.bravo, olatz.garcia, concepcion.varela, m.rodriguez, \\ purificacion.gonzalez\}@ehu.es
}

Received: June 2006

\begin{abstract}
In this paper an agreed set of standards, procedures and guidelines on quality assurance for the emergent European Higher Education Area is presented. If this set is implemented, the procedures for the recognition of qualifications will be strengthened. The set has been divided in two groups: there are internal and external standards and guidelines. The internals should be implemented by higher education institutions and under their responsibility. The external standards and guidelines should be implemented by external agencies with the collaboration of the higher education institutions.
\end{abstract}

Keywords: quality, standards, procedures, guidelines, European Higher Education Area.

\section{Introduction}

In the Communiqué of the Conference of Ministers responsible for Higher Education in Berlin, 2003 (Berlin, 2003), it was suggested "to develop an agreed set of standards, procedures and guidelines on quality assurance and to explore ways of ensuring an adequate peer review system for quality assurance and/or accreditation agencies or bodies".

Quality assurance in higher education is not an exclusive preoccupation of Europe. All over the world there is an increasing interest in quality and standards, reflecting both the rapid growth of higher education and its cost to the public and the private purse. Accordingly, if Europe is to achieve its aspiration to be the most dynamic and knowledgebased economy in the world, then European higher education will need to demonstrate that it takes the quality of its programmes and awards seriously and is willing to put into place the means of assuring and demonstrating that quality. The commitment of all those involved in the production of these proposals augurs well for the fulfilment of a truly European dimension to quality assurance with which to reinforce the attractiveness of the higher education offering of the EHEA.

Some fundamental principles that we should consider in these initiatives are: 
- the interests of students as well as those of the employers and those of the society in general;

- the great importance of the institutional autonomy, clarified by the recognition that this one entails great responsibilities;

- the necessity that the external quality assurance adjusts to its intentions and to entrust to the institutions only the necessary and appropriate load for the achievement of its objectives.

The European Higher Education Area, with its 46 states, is characterised by its diversity of political systems, higher education systems, socio-cultural and educational traditions, languages, aspirations and expectations. And this is one of the glories of Europe.

This makes a single monolithic approach to quality, standards and quality assurance in higher education inappropriate. So, a narrow, prescriptive and highly formulated approach to standards should be rejected. The framework to a good quality assurance should be to lead to broad acceptance and for the approach of the different higher education communities across the EHEA. However, one consequence of the generic principle is that the standards and guidelines focus more on what should be done than how they should be achieved.

Next, a set of proposed standards and guidelines for quality assurance in the EHEA are set out (Standards, 2005), most of them accepted in the Conference of Ministers responsible for Higher Education in Bergen, 2005 (Bergen, 2005). But these standards and guidelines should not be interpreted as prescriptive or unchangeable.

\section{Internal and External Assurance}

Standards and guidelines are separated in two groups: internals and externals.

Higher education institutions have the primary responsibility for the quality of their provision and their assurance, so these institutions must take the opportune internal measures for its attainment.

External assurance has to come from standards and guidelines that can take different forms according to the systems and can include institutional evaluations of different types; subject or programme evaluations; accreditation at subject, programme and institutional levels; and combinations of these. External agencies will implement these standards and guidelines.

But, both in the internal and in the external assurances, there is the typical risk: commissions or agencies, which design, prepare, and write the guides and protocols where the standards will have place in, will be made up by members of the institutions that will be judged.

Someone can think that standards and guidelines are not a trial but a help for improving the quality of education. But we know that when time will go by, the standards and guidelines turn into objectives that must be filled. However, it is obvious that the presence of members in the commissions that know perfectly the universities and educational institutions is need. So, we think that joint commissions are the best way to satisfy both 
the high level of the standards and measures (internals and externals) and their adequate level to each institution.

Moreover, evaluations, programmes, accreditations, and all kind of these type of measures, must have itemization clear and public, in order to avoid inscrutability, contacts and string-pulling, 'favours for the boys', nepotism and any other type of fiddle.

\section{Standards and Guidelines for Internal Quality Assurance}

\subsection{Policy and Procedures for Quality Assurance}

Standard. Institutions should have a policy and associated procedures for the assurance of the quality and standards of their programmes and awards. They should also commit themselves explicitly to the development of a culture which recognises the importance of quality, and quality assurance, in their work. To achieve this, institutions should develop and implement a strategy for the continuous enhancement of quality.

The strategy, policy and procedures should have a formal status and be publicly available. They should also include a role for students and other stakeholders.

Guidelines. Formal policies and procedures provide a framework within which higher education institutions can develop and monitor the effectiveness of their quality assurance systems. Computer procedures have to be essentials. Nowadays, there are several institutional platforms that work in a similar way to manage the teaching assignment, groups of students, marks, etc. They can be adapted for the assurance systems, because the unique technical problem of managing and working with huge data base is solved (Stemposz et al., 2007).
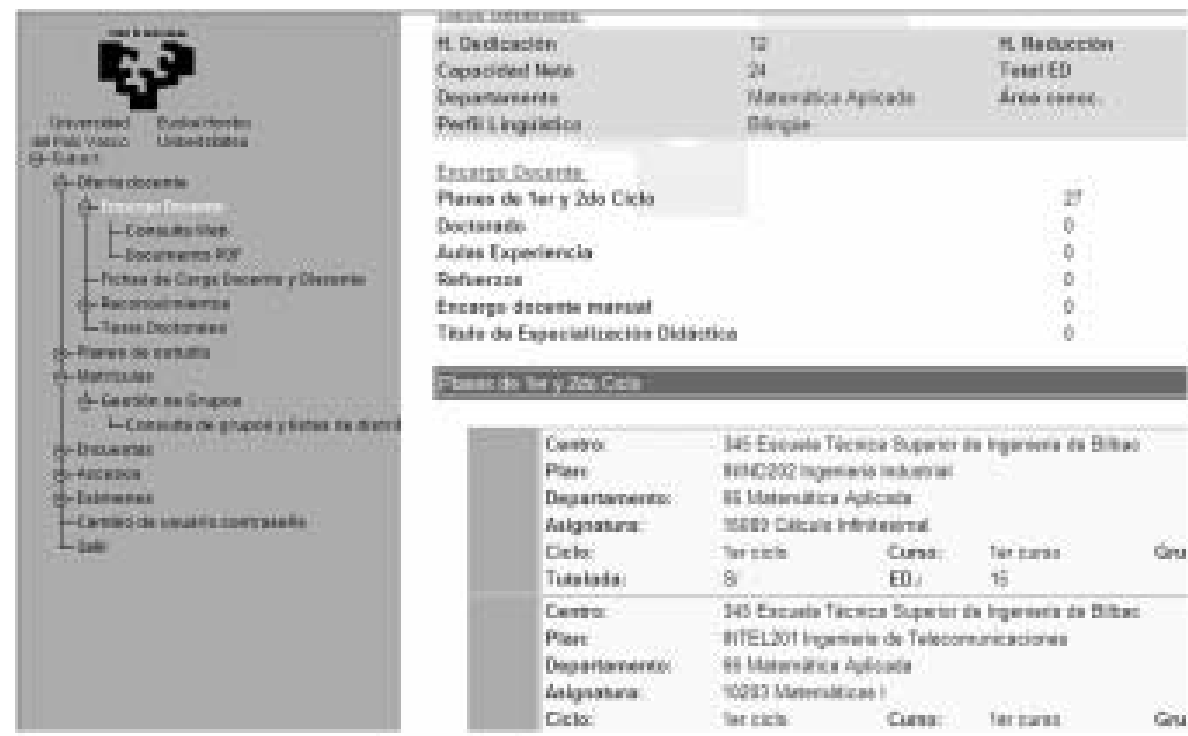

Fig. 1. Institutional platform for managing teaching assignment. 


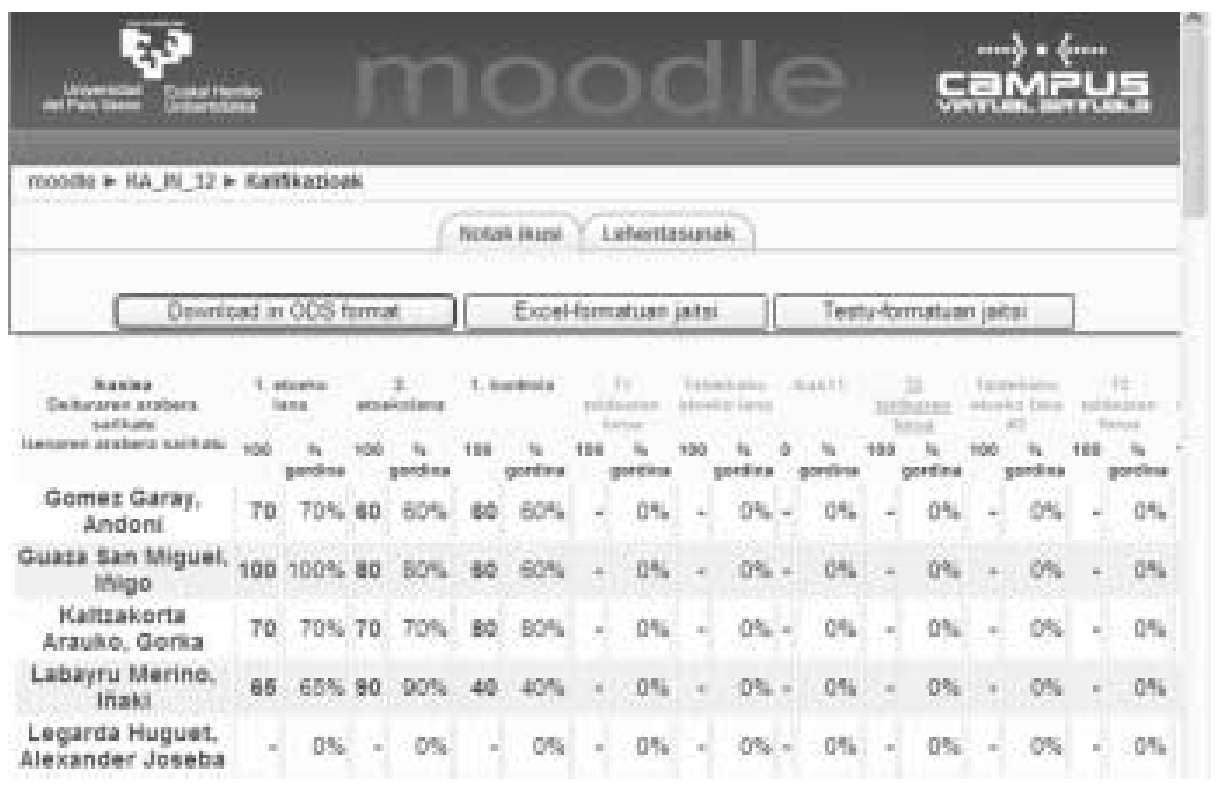

Fig. 2. Monitoring of students' tasks by Moodle platform.

Policies also help to provide public confidence in institutional autonomy. They contain the statements of intentions and the principal means by which these will be achieved. Procedural guidance can give more detailed information about the ways in which the policy is implemented and provides a useful reference point for those who need to know about the practical aspects of carrying out the procedures.

The policy statement is expected to include:

- the relationship between teaching and research in the institution;

- the institution's strategy for quality and standards;

- the organisation of the quality assurance system;

- the responsibilities of departments, schools, faculties and other organisational units and individuals for the assurance of quality;

- the involvement of students in quality assurance;

- the ways in which the policy is implemented, monitored and revised.

The realisation of the EHEA depends crucially on a commitment at all levels of an institution to ensuring that its programmes have clear and explicit intended outcomes; that its staff are ready, willing and able to provide teaching and learner support that will help its students achieve those outcomes; and that there is full, timely and tangible recognition of the contribution to its work by those of its staff who demonstrate particular excellence, expertise and dedication. All higher education institutions should aspire to improve and enhance the education they offer their students.

Higher educational institutions are improving their systems to contain the new technologies come from ICT, but they usually forget the human aspect. Sometimes institutions provide courses to update teachers' knowledge to the new ICT, but they do not do any- 
thing with these teachers that do not do any effort in order to update or adapt their selves to the new century (even with these teachers that torpedo the initiatives of their colleagues in the interests of the new time). Obligations is not the best way, but sometimes is not a bad option.

\subsection{Approval, Monitoring and Periodic Review of Programmes and Awards}

Standard. Institutions should have formal mechanisms for the approval, periodic review and monitoring of their programmes and awards.

Guidelines. The confidence of students and other stakeholders in higher education is more likely to be established and maintained through effective quality assurance activities which ensure that programmes are well-designed, regularly monitored and periodically reviewed, thereby securing their continuing relevance and currency.

Last years, students who accede to University from Secondary Studies do not bring the necessary formation to begin higher studies. On the one hand, the reform of curricula in Secondary Schools causes that, in general, they have attended less hours of those than they would be advisable to obtain the necessary and basic knowledge for the access to the university. On the other hand, the attitude of the pupils has undergone a gradual change that has taken to him to lack, almost completely, of ability to individual work.

Use of Informatics and ICT is one of the keys to diminish the gap between Secondary Studies and University. For example, the use of audiovisual and interactive materials selfmade by teachers will be an improvement in the quality and in the results (Bilbao et al., 2006; Bilbao et al., 2007).

The quality assurance of programmes and awards are expected to include:

- development and publication of explicit intended learning outcomes;

- careful attention to curriculum and programme design and content;

- specific needs of different modes of delivery (e.g. full time, part-time, distancelearning, e-learning) and types of higher education (e.g. academic, vocational, professional);

- availability of appropriate learning resources;

- formal programme approval procedures by a body other than that teaching the programme;

- monitoring of the progress and achievements of students;

- regular periodic reviews of programmes (including external panel members);

- regular feedback from employers, labour market representatives and other relevant organisations;

- participation of students in quality assurance activities.

\subsection{Assessment of Students}

Standard. Students should be assessed using published criteria, regulations and procedures which are applied consistently.

Guidelines. The assessment of students is one of the most important elements of higher education. The outcomes of assessment have a profound effect on students' future careers. It is therefore important that assessment is carried out professionally at all times 
and takes into account the extensive knowledge which exists about testing and examination processes. Assessment also provides valuable information for institutions about the effectiveness of teaching and learners' support.

Student assessment procedures are expected to:

- be designed to measure the achievement of the intended learning outcomes and other programme objectives;

- be appropriate for their purpose, whether diagnostic, formative or additive;

- conceive and to use the evaluation like an integrated instrument in the process education-learning that allows to provide feedback to students (precise information on the areas in which to improve) and to the teacher (indicating the changes to him who must make with the purpose of improving his methods);

- play an orientation and impelling role of the work of students so that these perceive the evaluation like real help, generating of positive expectations;

- extend to all the aspects: conceptual, procedural and of attitude;

- be developed throughout all the process education-learning and not to have only character of terminal valuation;

- have clear and published criteria for marking;

- be undertaken by people who understand the role of assessment in the progression of students towards the achievement of the knowledge and skills associated with their intended qualification;

- where possible, not rely on the judgements of single examiners;

- take account of all the possible consequences of examination regulations;

- have clear regulations covering student absence, illness and other mitigating circumstances;

- ensure that assessments are conducted securely in accordance with the institution's stated procedures;

- be subject to administrative verification checks to ensure the accuracy of the procedures.

In addition, students should be clearly informed about the assessment strategy being used for their programme, what examinations or other assessment methods they will be subject to, what will be expected of them, and the criteria that will be applied to the assessment of their performance.

\subsection{Quality Assurance of Teaching Staff}

Standard. Institutions should have ways of satisfying themselves that staff involved with the teaching of students is qualified and competent to do so. They should be available to those undertaking external reviews, and commented upon in reports.

Guidelines. Teachers are the single most important learning resource available to most students. It is important that those who teach have a full knowledge and understanding of the subject they are teaching, have the necessary skills and experience to transmit their knowledge and understanding effectively to students in a range of teaching contexts, and can access feedback on their own performance. Institutions should ensure that their staff 
recruitment and appointment procedures include a means of making certain that all new staff have at least the minimum necessary level of competence. Teaching staff should be given opportunities to develop and extend their teaching capacity and should be encouraged to value their skills. Institutions should provide poor teachers with opportunities to improve their skills to an acceptable level and should have the means to remove them from their teaching duties if they continue to be demonstrably ineffective.

But we do not have to limit to the subject knowledge and to the communication skills. For example, as we are doing in our university, teachers can improve their technological skills by means of courses to use Moodle platform, use and develop Mathematica software, develop web services, etc. (Bilbao et al., 2006).

\subsection{Learning Resources and Student Support}

Standard. Institutions should ensure that the resources available for the support of student learning are adequate and appropriate for each programme offered.

Guidelines. In addition to their teachers, students rely on a range of resources to assist their learning. These vary from physical resources such as libraries or computing facilities to human support in the form of tutors, counsellors, and other advisers. Learning resources and other support mechanisms should be readily accessible to students, designed with their needs in mind and responsive to feedback from those who use the services provided. Institutions should routinely monitor, review and improve the effectiveness of the support services available to their students.

Use of computers is essential with new tools as wikis, blogs, etc. We can not forget that young people are digital natives versus us, digital emigrants (Prensky, 2001).

As we have mentioned, for last years, it is observed that the students who accede to University from Secondary Studies do not bring the necessary formation to begin higher studies. On the one hand, the reform of curricula in Secondary Schools causes that, in general, they have attended less hours of those than they would be advisable to obtain the necessary and basic knowledge for the access to the university. On the other hand, the attitude of the pupils has undergone a gradual change that has taken to him to lack, almost completely, of ability to individual work (in contrast, the group work has been promoted and improved). That is to say, the problem is not only the lack of knowledge, but this one is clearly aggravated by the fact of the lack of habit, that in some cases even arrives at the incapacity, to face the work and individual effort that higher studies require.

In order to try to palliate the first of these problems, deficiencies in the knowledge, have started up some measures at university level in some European universities. Among these measures, we may emphasize the called 'zero course' in basic matters. Although it does not seem the suitable tool, because the ideal would be to correct the problems in inferior levels (such as Secondary School), at least it is of easy application since its beginning depends solely on the own university.

The second detected problem does not have simple solution. To modify study habits requires a set of measures that involve the own student.

The foundation of the learning and education based on the ECTS, where the base is the own learning of the student and where his work is considered, must be a sharp shock 
for that student. An exhaustive knowledge on the part of the student of the competitions who must reach, the methodology that is going away to follow, and the evaluation that teachers will implement, must stimulate his desire to learn.

\subsection{Information Systems}

Standard. Institutions should ensure that they collect, analyse and use relevant information for the effective management of their programmes of study and other activities.

Guidelines. Institutional self-knowledge is the starting point for effective quality assurance. It is important that institutions have the means of collecting and analysing information about their own activities. Without this they will not know what is working well and what needs attention, or the results of innovatory practices.

The quality-related information systems required by individual institutions will depend to some extent on local circumstances, but it is at least expected to cover:

- student progression and success rates;

- employability of graduates;

- students' satisfaction with their programmes;

- effectiveness of teachers;

- profile of the student population;

- learning resources available and their costs;

- the institution's own key performance indicators.

There is also value in institutions comparing themselves with other similar organisations within the EHEA and beyond. This allows them to extend the range of their self-knowledge and to access possible ways of improving their own performance.

\subsection{Public Information}

Standard. Institutions should regularly publish up to date, impartial and objective information, both quantitative and qualitative, about the programmes and awards they are offering.

Guidelines. In fulfilment of their public role, higher education institutions have a responsibility to provide information about the programmes they are offering, the intended learning outcomes of these, the qualifications they award, the teaching, learning and assessment procedures used, and the learning opportunities available to their students. Published information might also include the views and employment destinations of past students and the profile of the current student population. This information should be accurate, impartial, objective and readily accessible and should not be used simply as a marketing opportunity. The institution should verify that it meets its own expectations in respect of impartiality and objectivity. 


\section{Standards and Guidelines for the External Quality Assurance of Higher Education}

\subsection{Use of Internal Quality Assurance Procedures}

Standard. External quality assurance procedures should take into account the effectiveness of the internal quality assurance processes described in Part 1 of the European Standards and Guidelines.

Guidelines. The standards for internal quality assurance contained in Part 1 provide a valuable basis for the external quality assessment process. It is important that the institutions' own internal policies and procedures are carefully evaluated in the course of external procedures, to determine the extent to which the standards are being met.

If higher education institutions are to be able to demonstrate the effectiveness of their own internal quality assurance processes, and if those processes properly assure quality and standards, then external processes might be less intensive than otherwise.

\subsection{Development of External Quality Assurance Processes}

Standard. The aims and objectives of quality assurance processes should be determined before the processes themselves are developed, by all those responsible (including higher education institutions) and should be published with a description of the procedures to be used.

Guidelines. In order to ensure clarity of purpose and transparency of procedures, external quality assurance methods should be designed and developed through a process involving key stakeholders, including higher education institutions. The procedures that are finally agreed should be published and should contain explicit statements of the aims and objectives of the processes as well as a description of the procedures to be used.

As external quality assurance makes demands on the institutions involved, a preliminary impact assessment should be undertaken to ensure that the procedures to be adopted are appropriate and do not interfere more than necessary with the normal work of higher education institutions.

\subsection{Criteria for Decisions}

Standard. Any formal decisions made as a result of an external quality assurance activity should be based on explicit published criteria that are applied consistently.

Guidelines. Formal decisions made by quality assurance agencies have a significant impact on the institutions and programmes that are judged. In the interests of equity and reliability, decisions should be based on published criteria and interpreted in a consistent manner. Conclusions should be based on recorded evidence and agencies should have in place ways of moderating conclusions, if necessary.

Criteria and evidences must include computer aided tools (use and development). It is not ethical, just and a good practice to valuate in the same way the teaching task to those that do not use any computer tool and to those that are opening ways to new methods of education. 


\subsection{Processes Fit for Purpose}

Standard. All external quality assurance processes should be designed specifically to ensure their fitness to achieve the aims and objectives set for them.

Guidelines. Quality assurance agencies within the EHEA undertake different external processes for different purposes and in different ways. It is of the first importance that agencies should operate procedures which are fit for their own defined and published purposes. Experience has shown, however, that there are some widely-used elements of external review processes which not only help to ensure their validity, reliability and usefulness, but also provide a basis for the European dimension to quality assurance.

Amongst these elements the following are particularly noteworthy:

- insistence that the experts undertaking the external quality assurance activity have appropriate skills and are competent to perform their task;

- the exercise of care in the selection of experts;

- the provision of appropriate briefing or training for experts;

- the use of international experts;

- participation of students;

- ensuring that the review procedures used are sufficient to provide adequate evidence to support the findings and conclusions reached;

- the use of the self-evaluation/site visit/draft report/published report/follow-up model of review;

- recognition of the importance of institutional improvement and enhancement policies as a fundamental element in the assurance of quality.

\subsection{Reporting}

Standard. Reports should be published and should be written in a style which is clear and readily accessible to its intended readership. Any decisions, commendations or recommendations contained in reports should be easy for a reader to find.

Guidelines. In order to ensure maximum benefit from external quality assurance processes, it is important that reports should meet the identified needs of the intended readership. Reports are sometimes intended for different readership groups and this will require careful attention to structure, content, style and tone.

In general, reports should be structured to cover description, analysis (including relevant evidence), conclusions, commendations, and recommendations. There should be sufficient preliminary explanation to enable a lay reader to understand the purposes of the review, its form, and the criteria used in making decisions. Key findings, conclusions and recommendations should be easily locatable by readers.

Reports should be published in a readily accessible form and there should be opportunities for readers and users of the reports (both within the relevant institution and outside it) to comment on their usefulness. 


\subsection{Follow-up Procedures}

Standard. Quality assurance processes which contain recommendations for action or which require a subsequent action plan, should have a predetermined follow-up procedure which is implemented consistently.

Guidelines. Quality assurance is not principally about individual external scrutiny events: It should be about continuously trying to do a better job. External quality assurance does not end with the publication of the report and should include a structured follow-up procedure to ensure that recommendations are dealt with appropriately and any required action plans drawn up and implemented. This may involve further meetings with institutional or programme representatives. The objective is to ensure that areas identified for improvement are dealt with speedily and that further enhancement is encouraged.

\subsection{Periodic Reviews}

Standard. External quality assurance of institutions and/or programmes should be undertaken on a cyclical basis. The length of the cycle and the review procedures to be used should be clearly defined and published in advance.

Guidelines. Quality assurance is not a static but a dynamic process. It should be continuous and not "once in a life-time". It does not end with the first review or with the completion of the formal follow-up procedure. It has to be periodically renewed. Subsequent external reviews should take into account progress that has been made since the previous event. The process to be used in all external reviews should be clearly defined by the external quality assurance agency and its demands on institutions should not be greater than are necessary for the achievement of its objectives.

\subsection{System-wide Analyses}

Standard. Quality assurance agencies should produce from time to time summary reports describing and analysing the general findings of their reviews, evaluations, assessments, etc.

Guidelines. All external quality assurance agencies collect a wealth of information about individual programmes and/or institutions and this provides material for structured analyses across whole higher education systems. Such analyses can provide very useful information about developments, trends, emerging good practice and areas of persistent difficulty or weakness and can become useful tools for policy development and quality enhancement. Agencies should consider including a research and development function within their activities, to help them extract maximum benefit from their work.

\section{Conclusions}

A set of proposed standards and guidelines for quality assurance in the EHEA are presented in this paper, most of them accepted in the Conference of Ministers responsible for Higher Education in Bergen, 2005. 
The proposals offer increased transparency, security and information about higher education for students and society more generally.

Some examples of proposals with the use of Informatics have been given. In this sense, our opinion is that a fresh and determined impetus of the computer use for teaching and learning is fundamental in order to improve the quality of the education and the results of examinations of the students.

The implementation of the proposals will take longer for the internal and external quality assurance standards to be widely adopted by institutions and agencies, because their acceptance will depend on a willingness to change and develop on the part of the countries with long-established and powerful higher education systems.

The proposals will remain no more than proposals, however, if they are not accompanied by an effective implementation strategy. In addition, these standards and guidelines should not be interpreted as prescriptive or unchangeable. And it is necessary to involve Secondary School in the process in order to improve the learning of those students who will register in a centre of the EHEA.

\section{References}

Bergen (2005). The European higher education area: achieving the goals. In Communiqué of the Conference of European Ministers Responsible for Higher Education, Bergen, 19-20 May 2005.

Berlin (2003). Realising the European higher education area. In Communiqué of the Conference of Ministers responsible for Higher Education, Berlin, 19 September 2003.

Bilbao, J., Bravo, E. and González, P. (2006). La educación universitaria en tiempos de cambio (in Spanish, University education in time of change). In Servicio Editorial UPV/EHU, 293-304.

Bilbao, J., Bravo, E., González, P. and Chicote, J. (2007). MateOnLine: web application to use mathematica locally. Informatics in Education, 1(6), 19-42.

Bilbao, J., García, O., Rodríguez, M., Varela, C., Bravo, E., González, P. and Valdenebro, V. (2006). When the class finishes or it has not still begun. Wseas Trans. on Advances in Engineering Education, 11(3), 1030 1035.

Prensky, M. (2001). Digital natives, digital immigrants. On the Horizon. NCB University Press, 9(5). http: / / www . marcprensky. com/writing/Prensky 20-\%20Digital\%20Natives, \%2 0Digital\%20Immigrants\%20-\%20Part1.pdf

Standards (2005). Standards and Guidelines for Quality Assurance in the European Higher Education Area. European Association for Quality Assurance in Higher Education.

Stemposz, E., Stasiecka, A. and Jodlowski, A. (2007). The proposal of metadata for defining the quality of e-learning. In ENMA 2007, 357-364.

J. Bilbao obtained the degree in electrical engineering from University of the Basque Country, Spain, in 1991. At present he is $\mathrm{PhD}$ in applied mathematics and professor at the Department of Applied Mathematics of that university.

E. Bravo obtained the degree in electrical engineering from University of the Basque Country, Spain, in 1991. At present he is $\mathrm{PhD}$ in applied mathematics and professor at the Department of Applied Mathematics of that university.

O. García obtained the degree in mathematics from University of the Basque Country, Spain, in 1989. At present she is $\mathrm{PhD}$ in applied mathematics and professor at the Department of Applied Mathematics of that university. 
C. Varela obtained the degree in mathematics from UNED, Spain, in 1986. At present she is $\mathrm{PhD}$ in economics and statistics and professor at the Department of Applied Mathematics of that university.

M. Rodríguez obtained the degree in physics from University of Navarra, Spain, in 1978. At present he is $\mathrm{PhD}$ in electronic engineering and professor at the Department of Applied Mathematics of that university.

P. González obtained the degree in energetics engineering from University of the Basque Country, Spain, in 1979. At present she is $\mathrm{PhD}$ in applied mathematics and professor at the Department of Applied Mathematics of that university and head of the department. 


\section{Europos aukštojo mokslo įvariu sričiu susietumas su informatikos naudojimu}

Javier BILBAO, Eugenio BRAVO, Olatz GARCÍA, Concepción VARELA, Miguel RODRÍGUEZ, Purificación GONZÁLEZ

Šiame straipsnyje aptariamos kokybės standartu, procedūru ir rekomendacijų, taikomų Europos aukštojo mokslo ivvarioms sritims, garantijos. Kai rekomendacijos bus igyvendintos, tai kvalifikaciju atpažinimo procedūra sustiprès. Kriterijai padalinti ị dvi grupes: vidinius ir išorinius standartus bei rekomendacijas. Vidinius standartus turètụ igyvendinti ir už juos būti atsakingos aukštojo mokslo įstaigos. Išorinius standartus turètu igyvendinti išorinès institucijos, bendradarbiaudamos su aukštojo mokslo įstaigomis. 